\title{
Dioctyl phthalate increases the percentage of unsaturated fatty acids with a concomitant decrease in cellular heat shock sensitivity in the yeast Saccharomyces cerevisiae
}

\author{
Brendan P. G. Curran, Seunath A. Khalawan and Mahua T. Chatterjee
}

School of Biological Sciences, Queen Mary and Westfield College, Mile End Road, London E1 4NS, UK

\author{
Author for correspondence: Brendan P. G. Curran. Tel: +44 207775 3013. Fax: + 442089830973. \\ e-mail: B.Curran@qmw.ac.uk
}

\begin{abstract}
In the past it has been reproducibly demonstrated that $37{ }^{\circ} \mathrm{C}$-grown DBY747 yeast cells have $29 \%$ more unsaturated fatty acids and a $3{ }^{\circ} \mathrm{C}$ higher maximal heat shock response (HSR) than their $25^{\circ} \mathrm{C}$ counterparts. Suddenly the HSR and lipid profiles of cells grown at $25^{\circ} \mathrm{C}$ and $37^{\circ} \mathrm{C}$ became indistinguishable from one another. This paper reports an aberrantly high level of unsaturated fatty acids and an abnormally insensitive HSR in cells grown at $25^{\circ} \mathrm{C}$ in yeast nitrogen base (YNB) that has been reconstituted from dehydrated medium packaged in 'new' plastic containers. Effective even at a 1:600 dilution of reconstituted medium in laboratory-made YNB, the 'active ingredient' was identified using a combination of HPLC and mass spectroscopy as dioctyl phthalate (a plasticising agent). Furthermore, the same levels of increase in the percentage of unsaturated fatty acids and decrease in the sensitivity of HSR were found in cells grown in laboratory-made YNB that contained as little as $36 \mu \mathrm{M}$ pure dioctyl phthalate. This compound nevertheless failed to elicit an observable effect on cellular growth rate at levels up to and including $144 \mu \mathrm{M}$. These results suggest that dioctyl phthalate causes yeast cells to accumulate high levels of unsaturated fatty acids with a concomitant decrease in the sensitivity of the HSR, without compromising overall cellular function. They also support earlier work that suggested that the HSR is exquisitely sensitive to the level of unsaturated fatty acids present in yeast cells.
\end{abstract}

Keywords: Dioctyl phthalate, lipids, yeast, heat shock response

\section{INTRODUCTION}

In common with other living organisms, normal metabolic functions are suppressed and genes encoding heat shock proteins induced when yeast cells are exposed to a sublethal heat shock (reviewed by Mager \& De Kruijff, 1995). The accumulation of denatured cellular proteins is widely regarded as the trigger for the induction of these genes but the precise mechanism by which heat stress is transduced into an intracellular signal remains largely unknown (reviewed by Parsell \& Lindquist, 1993). The heat shock response (HSR) is transient, with a rapid induction of heat shock proteins when yeast cells are shifted from $25^{\circ} \mathrm{C}$ to $37^{\circ} \mathrm{C}$, followed by a decline to a new basal level of activity, which remains constant for

Abbreviations: HSE, heat shock element; HSR, heat shock response. as long as the cells are maintained at the higher temperature (Miller et al., 1979; Slater \& Craig, 1987; Sorger, 1990, 1991). This observation is not consistent with a HSR model in which thermally denatured proteins are the trigger for the response because a continuous heat shock should give rise to continual protein denaturation, thus necessitating the need for continual activation of the heat shock genes. Instead, the transient nature of the HSR strongly suggests that the heat-stress transduction mechanism can become desensitised, depending upon the prevailing conditions in the cell.

Intriguingly, the plasma membrane has been implicated in mechanisms of cellular stress (reviewed by Vigh et al., 1998), and membrane fluidity varies with changes in environmental temperature in a wide variety of different organisms, including Saccharomyces cerevisiae (Hunter 
\& Rose, 1972; Cronan, 1978; Okuyama et al., 1979; Suutari et al., 1990). Coote et al. (1991) noted that the yeast plasma membrane becomes leaky as a consequence of heat stress, resulting in an increased permeability to extracellular protons. They suggested that this intracellular acidification acted as a trigger for inducing tolerance to an otherwise lethal temperature challenge. Furthermore, Coote et al. (1994) used an ATPase mutant of Saccharomyces cerevisiae to demonstrate that this membrane-bound proton pump plays a key role in cellular thermotolerance. The activity of this enzyme has also been shown to affect both the level of expression of heat shock genes and the duration of time over which they are induced (Panaretou \& Piper, 1990) whereas in a separate study, minor intracellular acidification arising from ionophore treatment has been correlated with the expression of HSP70 in yeast (Weitzel et al., 1987). Furthermore, Kamada et al. (1995) provided evidence that thermal stress triggers the expression of the yeast PKC1 gene, by stretching the plasma membrane. Thus a number of disparate observations provide support for the view that cellular stress sensitivity is intimately associated with membrane structure and function. The direct manipulation of cellular fatty acids provides further evidence for this (Carratu et al., 1996; Chatterjee et al., 1997).

Carratu et al. (1996) found a decrease in the cellular heat shock sensitivity and an increase in unsaturated fatty acids in yeast cells overexpressing the ole 1 gene product. Previously published work from this laboratory (Chatterjee et al., 1997) demonstrated an equally strong correlation between the heat shock sensitivity of yeast and the type of fatty acid present in the cells. Expression of $\beta$-galactosidase from a heat shock reporter gene revealed that the temperature of maximum induction was $45^{\circ} \mathrm{C}, 47^{\circ} \mathrm{C}$ or $49^{\circ} \mathrm{C}$, depending on the type and percentage of unsaturated fatty acids present in cells after they had been grown on different lipid sources under anaerobic conditions. We also demonstrated that cells grown at $37^{\circ} \mathrm{C}$ have $29 \%$ more unsaturated fatty acids and a $3{ }^{\circ} \mathrm{C}$ higher maximal HSR than cells grown at $25^{\circ} \mathrm{C}$; an alteration in lipid profile and HSR sensitivity that we propose provides a possible mechanism to explain the transient nature of the HSR.

Despite multiple reproducible repeats of experiments that revealed these differences, suddenly the profiles of $\beta$ galactosidase induction from cells grown at $25^{\circ} \mathrm{C}$ and $37^{\circ} \mathrm{C}$ became indistinguishable from one another. Even more intriguingly, for no apparent reason the lipid profiles from the two sets of cells also became the same. Here, after many months of exhaustive analysis we provide an explanation for this abrupt change; an explanation that adds even further weight to the hypothesis that the HSR is intimately associated with membrane structure.

\section{METHODS}

Strains. Saccharomyces cerevisiae strain DBY747-HSE1 (MATa leu2-3,112 ura3 his3 trp1) was transformed to uracil prototrophy with the heat shock expression vector GA1695-
HSE1 (a kind gift of Dr P. Sorger, University of California, USA). GA1695-HSE1 contains a single heat shock element (HSE) sequence inserted in a disabled CYC1 promoter fused to the lacZ gene (Sorger \& Pelham, 1987). $\beta$-Galactosidase is not expressed at detectable levels in DBY747-HSE1 under normal conditions.

Overnight growth. DBY747-HSE1 was grown to exponential phase $\left(2 \times 10^{6}\right.$ cells $\left.\mathrm{ml}^{-1}\right)$ in $8 \times 60 \mathrm{ml}$ aliquots in $250 \mathrm{ml}$ conical flasks in a selection of yeast nitrogen base (YNB) media supplemented with histidine $\left(20 \mathrm{mg} \mathrm{l}^{-1}\right)$, leucine $(30 \mathrm{mg}$ $\left.\mathrm{l}^{-1}\right)$ and tryptophan $\left(20 \mathrm{mg} \mathrm{l}^{-1}\right)$. Cells were grown at $25^{\circ} \mathrm{C}$ or acclimatized in a $37^{\circ} \mathrm{C}$ shaking water bath for a period of $16 \mathrm{~h}$ (during which time cells were diluted with YNB selective medium to maintain exponential growth). Samples were analysed for temperature profiles of HSE-lacZ induction and/or lipid profiles at the specified time points.

Commercial YNB medium. YNB $(0.67 \%, \mathrm{w} / \mathrm{v})$ without amino acids (Difco), in 'old' or 'new' plastic containers, containing $2 \cdot 0 \%(\mathrm{w} / \mathrm{v})$ glucose was used.

'Home-made' YNB. Stock solutions of the compounds detailed below were made up and autoclaved, or where specified, filtersterilized. Stocks were stored at room temperature except where stated otherwise. Concentrations stated represent the final concentration in 11 medium. Monobasic potassium phosphate $\left(850 \mathrm{mg} \mathrm{l}^{-1}\right)$ and dibasic potassium phosphate $\left(150 \mathrm{mg} \mathrm{l}^{-1}\right)$ were made up to a stock concentration of $100 \times$ stated specification, and calcium chloride $\left(100 \mathrm{mg} \mathrm{l}^{-1}\right)$ was made up to a stock concentration of $1000 \times$ stated specification. Ammonium sulphate $\left(5 \mathrm{~g} \mathrm{l}^{-1}\right)$, sodium chloride $\left(100 \mathrm{mg} \mathrm{l}^{-1}\right)$ and magnesium sulphate $\left(500 \mathrm{mg} \mathrm{l}^{-1}\right)$ were each made up to a stock concentration of $50 \times$ stated specification. L-Methionine $\left(20 \mathrm{mg} \mathrm{l}^{-1}\right)$ was filter-sterilized. Dioctyl phthalate (serially diluted in ethanol) was added to the final concentration indicated, where appropriate.

The following vitamins were made up in a stock solution of $1000 \times$ stated specification, filter-sterilized and stored in aliquots of $1 \mathrm{ml}$ at $-20^{\circ} \mathrm{C}$ : biotin $\left(20 \mu \mathrm{g} \mathrm{l}^{-1}\right)$, calcium pantothenate $\left(2 \mathrm{mg} \mathrm{l}^{-1}\right)$, inositol $\left(10 \mathrm{mg} \mathrm{l}^{-1}\right)$, pyridoxine hydrochloride $\left(400 \mu \mathrm{g} \mathrm{l}^{-1}\right)$; thiamin hydrochloride $\left(400 \mu \mathrm{g} \mathrm{l}^{-1}\right)$, folic acid $\left(2 \mu \mathrm{g} \mathrm{l}^{-1}\right), p$-aminobenzoic acid $\left(200 \mu \mathrm{g}^{-1}\right)$, niacin $\left(400 \mu \mathrm{g} \mathrm{l}^{-1}\right)$ and riboflavin $\left(200 \mu \mathrm{g} \mathrm{l}^{-1}\right)$.

The following trace elements were made up in a stock solution of $1000 \times$ stated specification, filter-sterilized and stored in aliquots of $1 \mathrm{ml}$ at $-20{ }^{\circ} \mathrm{C}$ : boric acid $\left(500 \mu \mathrm{g} \mathrm{l}^{-1}\right)$, copper sulphate $\left(40 \mu \mathrm{g} \mathrm{l}^{-1}\right)$, zinc sulphate $\left(400 \mu \mathrm{g} \mathrm{l}^{-1}\right)$, potassium iodide $\left(100 \mu \mathrm{g} \mathrm{l}^{-1}\right)$, manganese sulphate $\left(400 \mu \mathrm{gl}^{-1}\right)$ and sodium molybdate $\left(200 \mu \mathrm{g} \mathrm{l}^{-1}\right)$. Ferric chloride $\left(200 \mu \mathrm{g} \mathrm{l}^{-1}\right)$ was made up as a stock solution of $500 \times$ stated specification, filtersterilized and stored in aliquots of $1 \mathrm{ml}$ at $-20{ }^{\circ} \mathrm{C}$

Determination of temperature profiles of HSE-lacZ. Aliquots $(10 \mathrm{ml})$ of exponentially growing cells were added to flasks containing $20 \mathrm{ml}$ liquid YNB medium or 'home-made' YNB as specified, pre-heated to the stated temperature (in $250 \mathrm{ml}$ conical flasks) in shaking water baths and subjected to a 10 min heat shock. The flasks were then placed in a $25^{\circ} \mathrm{C}$ shaking water bath for a further $50 \mathrm{~min}$ to allow $\beta$ galactosidase expression from the induced transcripts.

Measurement of $\beta$-galactosidase activity from total cell extracts. $\beta$-Galactosidase activity was measured from a total cell extract as previously described (Chatterjee et al., 1997). One representative set of experimental results (from at least three replicates) is presented for each temperature profile of 
HSE-lacZ expression. The absolute level of $\beta$-galactosidase varied between experiments but these profiles were reproduced in repeated separate experiments.

Determination of the cellular lipid profile. Lipids were extracted and analysed using a modification of the method described by Hossack \& Rose (1976) as previously described (Chatterjee et al., 1997). The mean value and range from at least two separate experiments are presented in each figure.

HPLC. Comparative HPLC was carried out on an LKB system using a 2150 hplc pump and a LKB 2151 variable-wavelength monitor. The system was de-gassed with helium before a $10 \mu \mathrm{l}$ sample was loaded on a Li-Chromosorb column RP-18 $(7 \mu \mathrm{m}$ particle size) and run on $35 \%$ acetonitryl $/ 65 \%$ water $(\mathrm{v} / \mathrm{v})$ at a flow rate of $1 \mathrm{ml} \mathrm{min}^{-1}$. Preparative HPLC was carried out under the same conditions except that repeated $10 \mu$ l aliquots of a 10 -fold concentrated YNB solution were added to the column until $0.5 \mathrm{ml}$ of the $22 \mathrm{~min}$ peak had been collected.

\section{RESULTS}

An unexplained $3^{\circ} \mathrm{C}$ shift in the temperature of maximal HSR in cells grown at $25^{\circ} \mathrm{C}$ correlates with an increase in the level of unsaturated fatty acids in the cell

Heretofore, cells grown overnight at $25^{\circ} \mathrm{C}$ and $37^{\circ} \mathrm{C}$ were differentially sensitive to heat shock, with peak induction at $40{ }^{\circ} \mathrm{C}$ for cells grown at $25^{\circ} \mathrm{C}$ and at $43^{\circ} \mathrm{C}$ for cells grown at $37^{\circ} \mathrm{C}$ (Fig. 1). Suddenly and inexplicably, the peak response of reporter gene expression was at $43{ }^{\circ} \mathrm{C}$ for cells grown at $25^{\circ} \mathrm{C}$, with an overall induction profile that had been previously restricted to cells grown at $37^{\circ} \mathrm{C}$ (Fig. 1). Furthermore, the cellular heat shock sensitivity was strongly correlated with the lipid profiles of these cells. Whereas in the past (Chatterjee et al., 1997), the cells grown at $25^{\circ} \mathrm{C}$ contained $36 \%$ unsaturated fatty acids and those grown at $37^{\circ} \mathrm{C}$ contained $65 \%$, now the cells grown at $25^{\circ} \mathrm{C}$ contained $73 \%$ unsaturated fatty acids (data not shown).

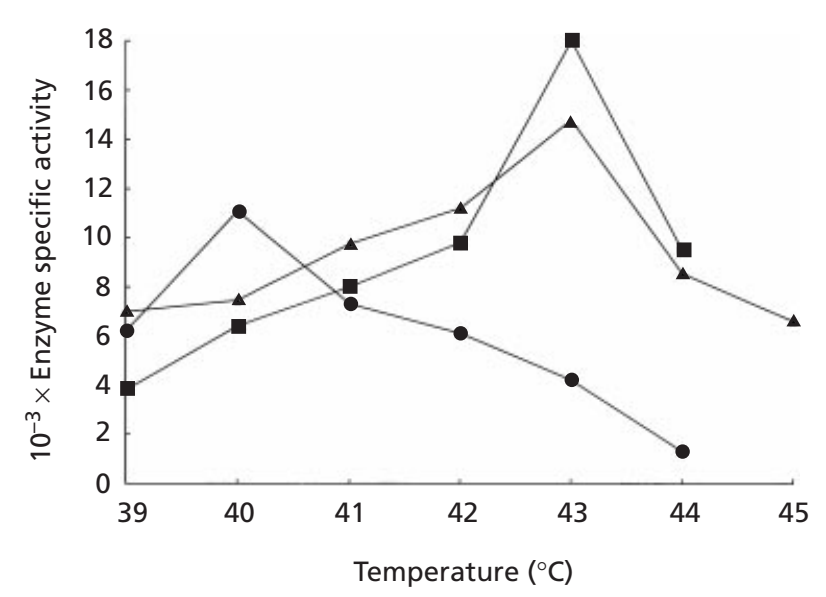

Fig. 1. Profile of heat shock induced $\beta$-galactosidase expression. 0 , cells grown at $25^{\circ} \mathrm{C}$ in 'old' YNB; $\mathbf{\square}$, cells grown at $37^{\circ} \mathrm{C}$ in 'old' YNB; $\boldsymbol{\Delta}$, cells grown at $25^{\circ} \mathrm{C}$ in 'new' YNB.

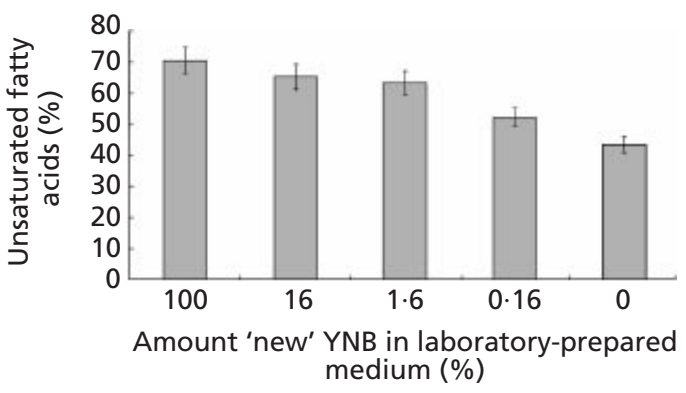

Fig. 2. Percentage of cellular unsaturated fatty acids in cells grown in 'home-made' YNB containing various percentages of 'new' YNB.

\section{Commercially produced YNB contains an extremely potent component}

The aberrant lipid profile of the cells disappeared when YNB was prepared from its basic constituents to the specifications of the YNB commercially available from Difco. Cells grown at $25^{\circ} \mathrm{C}$ in this 'home-made' YNB typically contained $44 \pm 5 \%$ unsaturated fatty acids (column 0 in Fig. 2). This was significantly different from the $71 \pm 7 \%$ found for cells grown in the current batch of commercially available YNB (column 100 in Fig. 2) but was, on the other hand, comparable to the $36 \pm 4 \%$ found for cells grown at $25^{\circ} \mathrm{C}$ in Difco's YNB in our previous experiments (Chatterjee et al., 1997). An analysis of the lipid content of cells grown in 'homemade' YNB 'spiked' with various volumes of a $0.67 \%$ solution of the 'new' YNB revealed that this batch of YNB was affecting lipid metabolism. Surprisingly the 'lipid-modifying component' of the 'new' YNB exerted an observable effect on the level of unsaturated fatty acids in yeast cells when as little as $0.1 \mathrm{ml}$ of the $0.67 \%$ solution was added to $59 \cdot 9 \mathrm{ml}$ of 'home-made' YNB $(0 \cdot 16 \%$ column in Fig. 2). Cells grown at this 1:600 dilution of the reconstituted YNB still contained 9\% more unsaturated fatty acids than cells that had been grown in the absence of 'new' YNB.

\section{HPLC identified a difference between 'old' and 'new' YNB}

An HPLC analysis of reconstituted medium from an old container of YNB ('old' YNB) and from a new container of YNB ('new' YNB) revealed a significant difference in elution profiles. A peak found to elute isocratically with $35 \%$ acetonitryl $/ 65 \%$ water $(\mathrm{v} / \mathrm{v})$ at a retention time of $22 \mathrm{~min}$ in the 'new' YNB did not appear in the 'old' YNB. Furthermore, a yeast bioassay revealed that cells exposed to as little as $100 \mu \mathrm{l}$ of this peak in $60 \mathrm{ml}$ of 'home-made' YNB synthesized $31 \%$ more unsaturated fatty acids than untreated control cells (Fig. 3, compare columns E and C). No such increase was apparent when cells were grown in the presence of $100 \mu \mathrm{l} 22 \mathrm{~min}$ fraction from the 'old' medium (Fig. 3, column D). The percentages of unsaturated fatty acids found in cells 


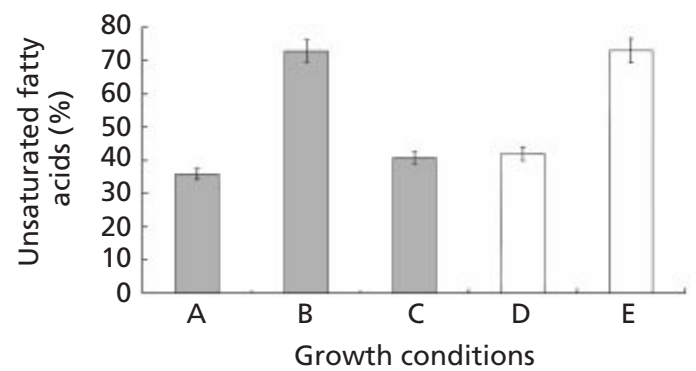

Fig. 3. Percentage of cellular unsaturated fatty acids in cells grown in 'old' YNB (A), 'new' YNB (B), 'home-made' YNB (C), 'home-made' YNB plus 'old' HPLC 22 min. sample (D), 'homemade' YNB plus 'new' HPLC 22 min sample (E).

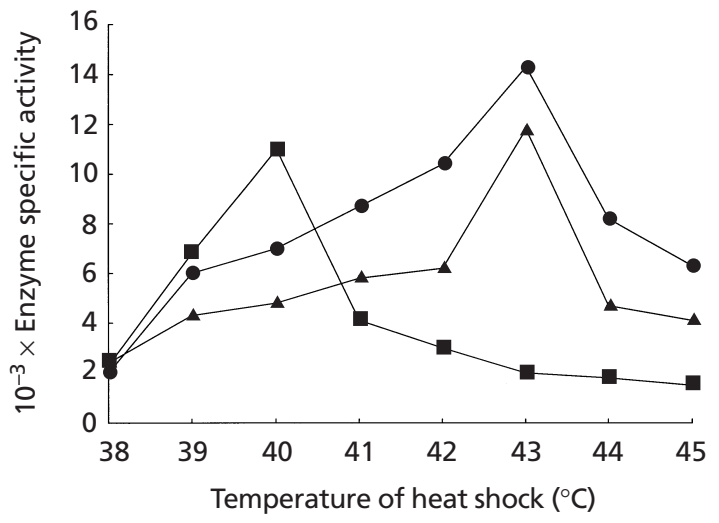

Fig. 4. Profile of heat shock-induced $\beta$-galactosidase expression for cells grown in 'home-made' YNB in the absence of dioctyl phthalate $(\boldsymbol{\square})$, in the presence of $36 \mu \mathrm{M}$ dioctyl phthalate $(\boldsymbol{\Delta})$, and in $37^{\circ} \mathrm{C}$ acclimatized cells in 'old' YNB medium (O).

grown in 'old' and 'new' YNB medium are included for comparison (Fig. 3, columns A and B, respectively).

Mass spectroscopy identified dioctyl phthalate in the 22 min peak from the 'new' YNB; it was undetectable in the corresponding fraction from the 'old' YNB. An analysis of cells grown in 'home-made' YNB containing pure dioctyl phthalate (Sigma) confirmed that this compound was indeed capable of altering lipid metabolism and with it the cellular HSR.

\section{Dioctyl phthalate increases the percentage of unsaturated fatty acids and decreases the cellular HSR sensitivity in yeast cells grown at $25^{\circ} \mathrm{C}$}

Within limits, the percentage of unsaturated fatty acids present in the cells was a reflection of the concentration of dioctyl phthalate present in the medium (data not shown). The percentage of unsaturated fatty acids found in cells that had been exposed to concentrations of dioctyl phthalate up to and including $18 \mu \mathrm{M}$ was indistinguishable from the $41 \%$ found in cells grown in the complete absence of this compound. However, there was a $21 \%$ increase in the percentage of unsaturated fatty acids in cells that had been exposed to $36 \mu \mathrm{M}$ dioctyl phthalate and an additional $15 \%$ increase, to $77 \%$, in cells exposed to $72 \mu \mathrm{M}$ dioctyl phthalate. A further doubling of dioctyl phthalate to $144 \mu \mathrm{M}$ failed to increase the percentage of unsaturated fatty acids above $77 \%$. The growth rates of these cultures were indistinguishable from one another but there was a significant decrease in the heat shock sensitivity of cells grown in the presence of dioctyl phthalate. The HSR profile of cells grown in the presence of $36 \mu \mathrm{M}$ dioctyl phthalate, the minimum level found to induce an increase in unsaturated fatty acids, is presented in Fig. 4.

Cells grown at $25^{\circ} \mathrm{C}$ in the absence of dioctyl phthalate had minimal induction of $\beta$-galactosidase from the heatinducible reporter gene at $38{ }^{\circ} \mathrm{C}$, with peak induction at $40^{\circ} \mathrm{C}$. In contrast, this same temperature elicited only low-level $\beta$-galactosidase induction in cells containing elevated levels of unsaturated fatty acids $(62 \%)$ after growth in the presence of $36 \mu \mathrm{M}$ phthalate. Furthermore, these cells underwent maximal induction at $43^{\circ} \mathrm{C}$; a temperature that elicited only a minimal response from cells grown in the absence of phthalate (Fig. 4). Cells grown at $37^{\circ} \mathrm{C}$ in the 'old' medium exhibited maximal $\beta$-galactosidase induction at $43^{\circ} \mathrm{C}$ (Fig. 4) and had $63 \%$ unsaturated fatty acids (Chatterjee et al., 1997). Thus the HSR and lipid profiles of cells grown at $25^{\circ} \mathrm{C}$ in 'home-made' medium containing $36 \mu \mathrm{M}$ dioctyl phthalate were the same as that found in cells that had been exposed to a $37^{\circ} \mathrm{C}$ heat shock in 'old' YNB; a pattern that was also found in cells grown at $25^{\circ} \mathrm{C}$ in 'new' medium (Fig. 1).

\section{DISCUSSION}

We have consistently found that the sensitivity of the yeast HSR system decreases as the level of unsaturated fatty acids increases in the cell. A typical example is provided in Fig. 1, where the $3{ }^{\circ} \mathrm{C}$ shift in the maximal HSR in cells grown at $25^{\circ} \mathrm{C}$ and $37^{\circ} \mathrm{C}$ was found to correlate with a $30 \%$ increase in the level of unsaturated fatty acids in the cell. Heat increases membrane fluidity; it is therefore counterintuitive that unsaturated fatty acids should be involved in desensitising a stressresponse system that exists to prevent heat stress from compromising cellular function. It could be argued that this increase in lipid unsaturation helps to maintain the overall fluidity of the membrane in the face of the accumulation of the stress-associated membrane proteins Tip1, Tip1 homologues (Kondo \& Inouye, 1991) and Hsp30 (Panaretou \& Piper, 1992). However, the lipid and HSR profiles of the cells that had been grown at $25^{\circ} \mathrm{C}$ in 'new' YNB in Fig. 1 cast doubt on this idea. These cells behaved in most respects like any other cells grown at $25^{\circ} \mathrm{C}$. They grew at the same rate and the heat shock reporter gene was off but their HSR and lipid profiles were the same as cells grown at $37^{\circ} \mathrm{C}$ in previous experiments using 'old' YNB.

The first indication that the aberrant lipid and HSR profiles were associated with commercially available YNB medium was when cells grown in 'home-made' 
YNB produced the same lipid and HSR profiles as cells grown in our earlier experiments. This can be seen in Fig. 2 where cells growing in 'new' YNB had $71 \%$ unsaturated fatty acids whereas cells growing in 'homemade' YNB only contained $44 \%$. Some idea of the potency of the 'lipid modifying compound' can be gleaned from the fact that cells grown in a dilution series (up to 1:600) of 'new' YNB in the 'home-made' variety still produced more unsaturated fatty acids than that found in the control cells (Fig. 2). This suggested that the 'new' medium contained rather than lacked a lipidmetabolism-modifying constituent and indeed, a comparative HPLC analysis revealed a novel elution peak at 22 min that was unique to the 'new' YNB.

The results presented in Fig. 3 indicate that this fraction does indeed contain the mystery contaminant. Cells produced $73 \%$ unsaturated fatty acids when grown in $60 \mathrm{ml}$ 'home-made' YNB in the presence of $100 \mu \mathrm{l}$ of the 22 min fraction from the 'new' YNB, but only $42 \%$ unsaturated fatty acids when $100 \mu \mathrm{l}$ from the equivalent peak of the 'old' YNB eluate was added (Fig. 3). Identified as dioctyl phthalate by mass spectroscopy, the results in Fig. 4 confirm the correlation between an increase in the level of unsaturated fatty acids in cells that have been grown in the presence of dioctyl phthalate and a decrease in their heat shock sensitivity. Cells grown at $25^{\circ} \mathrm{C}$ in the absence of dioctyl phthalate contained $41 \%$ unsaturated fatty acids and responded maximally to heat shock at $40{ }^{\circ} \mathrm{C}$, whereas cells grown in the presence of $36 \mu \mathrm{M}$ dioctyl phthalate had $62 \%$ unsaturated fatty acids and maximal induction of the reporter gene at $43^{\circ} \mathrm{C}$ (Fig. 4).

The mechanism by which phthalate has this effect on yeast cell lipid metabolism is unknown. In mammalian cells however, phthalate is known to induce peroxisome proliferation (reviewed by Latruffe \& Vamecq, 1997). Peroxisomes serve a major function in fatty acid oxidation (reviewed by Small et al., 1997) and indeed Rottensteiner et al. (1996) have shown that they are induced in Saccharomyces cerevisiae when oleic acid is supplied as the sole carbon source. It is unlikely however, that peroxisomes are induced under the growth conditions used here because peroxisomal structures and proteins are hardly detectable when glucose is present in the growth medium (Veenhuis et al., 1987; Filipits et al., 1993).

Phthalate is also known to increase the activity of protein kinase C (Bojes \& Thurman, 1996) in mammalian cells. It is possible therefore, that phthalate could affect the equivalent protein in yeast affecting MAP kinase pathways such as the cascade found to be involved in cell-wall metabolism in Saccharomyces cerevisiae (Hunter \& Plowman, 1997) or indeed by exerting an effect on yeast cell-cycle control (reviewed by Livneh \& Fishman, 1997). It is not difficult to imagine subsequent knock-on effects occurring on lipid metabolism under such circumstances.

The details of how this molecule brings about these changes remains to be elucidated but given that a $1 \mathrm{~h}$ exposure to $36 \mu \mathrm{M}$ dioctyl phthalate failed to induce $\beta$ galactosidase expression from this heat shock reporter gene (data not shown), dioctyl phthalate treatment appears to confer a decrease in yeast HSR sensitivity without inducing the response. Moreover, the growth rate of the cells used in these experiments was the same regardless of whether they were grown in $0,18,36,72$ or $144 \mu \mathrm{M}$ dioctyl phthalate, indicating that dioctyl phthalate does not significantly compromise overall cellular metabolism.

The results presented in this paper agree with earlier work from this laboratory that demonstrated that the percentage and type of fatty acid present in the cells determine the heat shock sensitivity of yeast cells (Chatterjee et al., 1997). It also agrees with the work of Carratu et al. (1996), who decreased the HSR sensitivity of yeast cells grown at $25^{\circ} \mathrm{C}$ by overexpressing the Ole1 gene product. Heat stress (Chatterjee et al., 1997), overexpression of the Ole1 gene product (Carratu et al. 1996), fatty acid supplements (Chatterjee et al., 1997) and dioctyl phthalate (Fig. 4) all increase the percentage of cellular unsaturated fatty acids and decrease the sensitivity of the cellular HSR system, yet only the first of these is associated with induction of the HSR pathway. This indicates that even in the absence of stress-induced proteins, an increase in the percentage of unsaturated fatty acids is sufficient to decrease the HSR sensitivity of yeast cells.

Phthalate contamination of YNB prevented us from reproducing our earlier results for many months. It is indeed a strange irony that rather than undermining the original observations, it eventually provided even further support for the counterintuitive hypothesis that the down-regulation of the yeast 'heat-sensing mechanism' is intimately associated with an increase in the percentage of unsaturated fatty acids present in the cell.

\section{ACKNOWLEDGEMENTS}

We thank Alan Scott for expert technical assistance with HPLC and lipid analysis and Dr Virginia Bugeja for critically reading the manuscript.

\section{REFERENCES}

Bojes, H. K. \& Thurman, R. G. (1996). Potent peroxisome proliferators inhibit beta-oxidation in the isolated perfused rat liver. Toxicol Appl Pharmacol 140, 322-327.

Carratu, L., Franceschelli, S., Pardini, C. L., Kobayashi, G. S., Horvath, I., Vigh, L. \& Maresca, B. (1996). Membrane lipid perturbation modifies the set point of the temperature of heat shock response in yeast. Proc Natl Acad Sci U S A 93, 3870-3875.

Chatterjee, M. T., Khalawan, S. A. \& Curran, B. P. G. (1997). Alterations in cellular lipids may be responsible for the transient nature of the yeast heat shock response. Microbiology 143, 3063-3068.

Coote, P. J., Cole, M. C. \& Jones, M. V. (1991). Induction of increased thermotolerance in Saccharomyces cerevisiae may be triggered by a mechanism involving intracellular $\mathrm{pH}$. J Gen Microbiol 137, 1701-1708. 
Coote, P. J., Jones, M. V., Seymour, I. J., Rowe, D. L., Ferdinando, D. P., McArthur, A. J. \& Cole, M. B. (1994). Activity of plasma membrane $\mathrm{H}^{+}$-ATPase is a key physiological determinant of thermotolerance in Saccharomyces cerevisiae. Microbiology 140, 1881-1890.

Cronan, J. E. (1978). Molecular biology of bacterial membrane lipids. Annu Rev Biochem 47, 163-189.

Filipits, M., Simon, M. M., Rapatz, W., Hamilton, B. \& Ruis, H. (1993). A Saccharomyces cerevisiae upstream activating sequence mediates induction of peroxisome proliferation by fatty acids. Gene 132, 49-55.

Hossack, J. A. \& Rose, A. H. (1976). Fragility of plasma membranes in Saccharomyces cerevisiae enriched with different sterols. J Bacteriol 127, 67-75.

Hunter, T. \& Plowman, G. D. (1997). The protein kinases of budding yeast: six score and more. Trends Biochem Sci 22, 18-21.

Hunter, K. \& Rose, A. H. (1972). Lipid composition of Saccharomyces cerevisiae as influenced by growth temperature. Biochim Biophys Acta 260, 639-653.

Kamada, Y., Jung, U. S., Piotrowski, J. \& Levin, D. E. (1995). The protein kinase C-activated MAP kinase pathway of Saccharomyces cerevisiae mediates a novel aspect of the heat shock response. Genes Dev 9, 1559-1571.

Kondo, K. \& Inouye, M. (1991). TIP1, a cold shock-inducible gene of Saccharomyces cerevisiae. J Biol Chem 266, 17537-17544.

Latruffe, N. \& Vamecq, J. (1997). Peroxisome proliferators and peroxisome proliferator activated receptors (PPARs) as regulators of lipid metabolism. Biochimie 79, 81-94.

Livneh, E. \& Fishman, D. D. (1997). Linking protein kinase C to cell-cycle control. Eur J Biochem 248, 1-9.

Mager, W. H. \& De Kruijff, A. J. J. (1995). Stress-induced transcriptional activation. Microbiol Rev 59, 506-531.

Miller, M. J., Xuong, N. \& Geiduschek, E. P. (1979). A response of protein synthesis to temperature shift in the yeast Saccharomyces cerevisiae. Proc Natl Acad Sci U S A 76, 5222-5225.

Okuyama, H., Saito, M., Joshi, V. C., Gunsberg, S. \& Wakil, S. L. (1979). Regulation by temperature of the chain length of fatty acids in yeast. J Biol Chem 254, 12281-12284.

Panaretou, B. \& Piper, P. W. (1990). Plasma-membrane ATPase action affects several stress tolerances of Saccharomyces cerevisiae and Schizosaccharomyces pombe as well as the extent and duration of the heat shock response. J Gen Microbiol 136, 1763-1770.
Panaretou, B. \& Piper, P. W. (1992). The plasma membrane of yeast acquires a novel heat shock protein (Hsp30) and displays a decline in proton-pumping ATPase levels in response to both heat shock and the entry to stationary phase. Eur J Biochem 206, 635-640.

Parsell, D. A. \& Lindquist, S. (1993). The function of heat shock proteins in stress tolerance: degradation and reactivation of damaged proteins. Annu Rev Genet 27, 437-496.

Rottensteiner, H., Kal, A. J., Filipits, M., Binder, M., Hamilton, B., Tabak, H. F. \& Ruis, H. (1996). Pip2p: a transcriptional regulator of peroxisome proliferation in the yeast Saccharomyces cerevisiae. EMBO J 15, 2924-2934.

Slater, M. R. \& Craig, E. A. (1987). Transcriptional regulation of an Hsp70 heat shock gene in the yeast Saccharomyces cerevisiae. Mol Cell Biol 7, 1906-1916.

Small, G. M., Karpichev, I. V. \& Luo, Y. (1997). Regulation of peroxisomal fatty acyl-CoA oxidase in the yeast, Saccharomyces cerevisiae. Adv Exp Med Biol 422, 157-166.

Sorger, P. K. (1990). Yeast heat shock factor contains separable transient and sustained response transcriptional activators. Cell 62, 793-805.

Sorger, P. K. (1991). Heat shock factor and the heat shock response. Cell 65, 363-366.

Sorger, P. K. \& Pelham, H. R. B. (1987). Purification and characterization of a heat shock element binding protein from yeast. EMBO J 6, 3035-3041.

Sorger, P. K., Lewis, M. J. \& Pelham, H. R. B. (1987). Heat shock factor is regulated differently in yeast and HeLa cells. Nature 329, 81-84.

Suutari, M., Liukkonen, K. \& Laakso, S. (1990). Temperature adaptation in yeasts: the role of fatty acids. J Gen Microbiol 136, 1469-1474.

Veenhuis, M., Mateblowski, M., Kunau, W. H. \& Harder, W. (1987). Proliferation of microbodies in Saccharomyces cerevisiae. Yeast 3, 77-84.

Vigh, L., Maresca, B. \& Harwood, J. L. (1998). Does the membrane's physical state control the expression of heat shock and other genes? Trends Biochem Sci 10,369-374.

Weitzel, G., Pilatus, U. \& Rensing, L. (1987). The cytoplasmic pH, ATP content and total protein synthesis rate during heat shock inducing treatments in yeast. Exp Cell Res 170, 64-79.

Received 11 April 2000; revised 25 May 2000; accepted 9 June 2000. 